\title{
GENETIC ANALYSIS FOR SOME PHENOLOGICAL AND MORPHOLOGICAL TRAITS IN WHEAT (TRITICUM AESTIVUM L.) UNDER TWO DIFFERENT SOWING WINDOWS
}

\author{
RAZA, H. $^{{ }^{*}}-$ KHAN, A. S. ${ }^{1}-$ AHMED, N. ${ }^{2}$ \\ ${ }^{1}$ Department of Plant Breeding and Genetics, University of Agriculture \\ Faisalabad 38040, Pakistan \\ ${ }^{2}$ Centre of Agricultural Biochemistry and Biotechnology, University of Agriculture \\ Faisalabad 38040, Pakistan \\ *Corresponding author \\ e-mail: humayunraza576@gmail.com \\ (Received 31 $1^{\text {st }}$ Oct 2018; accepted 21 ${ }^{\text {st }}$ Dec 2018)
}

\begin{abstract}
Major effect of climate change can be seen in developing countries like Pakistan that make them food insecure. Grain yield of wheat (Triticum aestivum L.) is low as it is affected by erratic weather conditions. Latest development of wheat genotypes applicable for late planting is one of the prime objectives of wheat breeders. Keeping in view the climatic conditions of Pakistan, current investigations were conducted to figure out the inheritance pattern and extent of variations using generation mean analysis. For the aforementioned study the two genotypes Miraj 2008 and Punjab 2011 were evaluated along with following generations i.e. $\mathrm{F}_{1}, \mathrm{~F}_{2}, \mathrm{BC}_{1}$ and $\mathrm{BC}_{2}$ in normal and late sowing trial in Faisalabad, Pakistan. The highest reduction percentage was observed in grain weight per spike $(-33.6 \%)$. The inheritance of all traits revealed complex inheritance due to the involvement of non-allelic interactions. The traits like days to heading and days to maturity had both additive, additive $\times$ additive i.e. fixable and additive $\times$ dominant non fixable genetic effects. So, selection in later generation would be fruitful for these traits when combinations are fixed. Heritability estimates for narrow sense was also determined. Low to moderate heritability was depicted under late sowing conditions.
\end{abstract}

Keywords: late planting, generation mean, reduction percentage, grain weight, heritability

\section{Introduction}

Crop yield is reducing due to adverse weather conditions whereas, supplies are becoming scarce, and the price is rising ultimately leads to food insecurity. Global mean temperature has risen at a rate of $0.3^{\circ} \mathrm{C}$ per decade during the twentieth-century (IFPRI, 2009) and is expected to reach 1 and $3^{\circ} \mathrm{C}$ above the current value by 2025 and 2100 respectively, resulting in more severe global climatic changes in near future. Heat stress (late sowing) at grain filling stage of wheat causes physiological and biochemical processes abort (Gupta et al., 2013). Therefore, selection of genotypes tolerant to high temperature with proper sowing time is a priority to manage the adverse effects of environments (Alghabari et al., 2014). Time of planting is one of the most important non-monetary input for optimizing the growth according to prevailing agro-climatic conditions and genotypes (Jena et al., 2017). It is an ultimate truth that crop yield is the inter-play of crop genetics, environment and management practices (Mirshekarnezhad et al., 2018). It is impossible to control the environment, but we can develop genotypes that can cope with changing environment. Among many other factors, late sowing is one of the major causes of lower wheat yield in Pakistan. Many cropping patterns prevailing in Pakistan have rotation like wheat; cotton, rice, maize, vegetables, fodders and sugarcane. This inertia in crop rotation cannot allow wheat to have an optimum 
time of plantation resulting in a large spectrum of sowing dates. About $80 \%$ of the wheat crop is grown after cotton, sugarcane and rice which exposes the crop to high temperature during the gain filling time that is the terminal heat stress which leads to drastic loss in grain yield and ultimately shortage of food (Prasad et al., 2011). High temperature is found to be accompanied with drought stress because of the rise in evapotranspiration. Terminal heat stress has drastic impacts on reproductive development such as flower initiation, ovary and pollen development, fertilization leading to reduction in sink potential which further results in yield loss (Barnabas et al., 2008). Selection of appropriate variety with respect to date of sowing is important to cope with the expected temperature rise at reproductive stage without compromising yield. Thus improvement in the crop genetic is the only inexpensive, effective and targeted approach available for wheat breeders in developing countries like Pakistan (Saxena and Toole, 2002). It is really important to know about genetic components as well as their interactions to achieve a workable breeding program. Generation mean analysis is a unique biometrical technique based on phenotypic performance of traits under study (Mather and Jinks, 1982). Generation mean analysis is most trusted biometric technique to investigate the genetic and epistatic effects. The present study was designed to achieve the information regarding the extent of variation and inheritance patterns in wheat genotypes under two different sowing windows.

\section{Materials and Methods}

\section{Plant material}

The current study was carried out in the research area of Department of Pant Breeding and Genetics University of Agriculture Faisalabad, Pakistan. The investigational material comprised of two bread wheat cultivars Miraj-2008 and Punjab2011 (Table 1) as parents and their generation's i.e. $\mathrm{F}_{1}, \mathrm{~F}_{2}, \mathrm{BC}_{1}$, and $\mathrm{BC}_{2}$ were established from two contrasting cultivars selected based on their planting time and commercial importance.

Table 1. Name and pedigree of parental bread wheat cultivars (spring type)

\begin{tabular}{c|c|c}
\hline Parent & Name & Pedigree \\
\hline 1 & Miraj-2008 & SPARROW/INIA/V7394/WL711/13/BAUS \\
2 & Punjab-2011 & AMSEL/ATTILA//INQ-91/PEW'S' \\
\hline
\end{tabular}

All six generations of cross were sown on November 15, 2015 under normal (optimum) sowing conditions. The research trial was conducted in randomized complete block design (RCBD) with three replicates $(\mathrm{P} \times \mathrm{P}=15 \mathrm{~cm} ; \mathrm{R} \times \mathrm{R}=30 \mathrm{~cm})$. Dibbler method was used for sowing. To attain a single vigorous seedling per hole thinning was done after germination. To abate the border effect lines of non-experimental material was sown at the border of the experiment. Total four irrigations were applied. First irrigation was applied at tillering stage, second at booting stage, third at anthesis stage, fourth at milking stage. Fertilizer were applied at the rate of $46 \mathrm{~kg}$ nitrogen, $34 \mathrm{~kg}$ phosphorus and $25 \mathrm{~kg}$ potash per acre. Twenty well-guarded plants from $\mathrm{P}_{1}, \mathrm{P}_{2}$ and $\mathrm{F}_{1}$ was tagged. Fifty plants from each back cross $\left(\mathrm{BC}_{1}\right.$ and $\left.\mathrm{BC}_{2}\right)$ and two hundred plants from $\mathrm{F}_{2}$ generation per replication were tagged prior to flowering. Similar activities were 
performed for the late sowing experiment on December 20, 2015. Harvesting was done 8-15 April, 2016. Data were recorded for the following traits: Plant height, tillers number per plant, Days taken to heading, days taken to maturity, grain filling duration $(E q .1)$, grain filling rate $(E q .2)$, harvest index $(E q .3)$ and grain weight per spike.

$$
\text { Grain filling duration }=\text { Days to maturity } \text { - days to heading }
$$

Grain filling rate was estimated using following formulae (Eq. 2):

$$
\begin{gathered}
\text { Grain filling rate }=\frac{\text { Grain yield }}{\text { Grain filling period }} \times 100 \\
\text { Harvest index }=\frac{\text { Grain yield }}{\text { Biological yield }} \times 100
\end{gathered}
$$

\section{Statistical analysis}

Analysis of variance was done following Steel et al. (1997) and generation mean analysis (Eq. 4) was performed according to the method given by Mather and Jinks (1982). A computer program provided by Dr. H.S. Pooni, School of Biological Sciences, University of Birmingham UK was used for generation mean analysis by the method of Mather and Jinks (1982). The narrow sense heritability $\left(h^{2} n s\right)$ was estimated by the method shown by Mather and Jinks (1982) and Saleem et al. (2016).

$$
\mathrm{Y}=\mathrm{m}+\alpha[\mathrm{d}]+\beta[\mathrm{h}]+\alpha^{2}[\mathrm{i}]+2 \alpha \beta[\mathrm{j}]+\beta^{2}[1]
$$

where $\mathrm{Y}=$ mean of one generation, $\mathrm{m}=$ mean of all the generations, $\mathrm{d}=$ sum of additive effects, $h=$ sum of dominance effects, $i=$ sum of additive $\times$ additive gene interaction i.e. complementary, $\mathrm{j}=$ sum of additive $\times$ dominance $\alpha^{2}, 2 \alpha \beta$ and $\beta^{2}$ were the coefficient of genetic parameters, $1=$ sum of dominance $\times$ dominance interaction i.e. duplicate.

\section{Results and discussion}

Understanding the genetic makeup of any crop plants is dire to batten the crop performance in the current scenario of climate change. Analysis of variance revealed significant genotypic difference for each generation $\left(\mathrm{P}_{1}, \mathrm{P}_{2}, \mathrm{~F}_{1}, \mathrm{~F}_{2}, \mathrm{BC}_{1}\right.$ and $\left.\mathrm{BC}_{2}\right)$ for all traits under study. Under both sowing conditions parents and generations exhibited significant differences (Table 2). The presence of genetic diversity in breeding material is basic criterion for success in any breeding program. Under different sowing conditions changed behavior of breeding material is an indication of significant environment into genotypes interaction (Akram, 2011; Saleem et al., 2016).

\section{Comparison of two treatment means of six generations of cross Miraj $2008 \times$ Punjab 2011 under normal and late sowing conditions}

Expression of genes in any stress become restricted. Under late sowing trial the overall performance of all the traits decreased. The magnitude of sensitivity was different for the different traits. Most sensitive traits grains weight per spike with a reduction of $33.6 \%$ succeeded by tillers number per plant $28.3 \%$ and harvest index 
$27.1 \%$. In contrast the lowest reduction was shown by days to heading $12.3 \%$ followed by grain filing rate $13.4 \%$ and grain filling duration $17.0 \%$ (Table 3). Scientists have also exhibited that under stressed environment, traits do not fully express themselves (Tahir et al., 2009; Sohail et al., 2014).

Table 2. Analysis of variance of different traits under studied of cross Miraj-2008 $\times$ Punjab2011 under normal and late sowing conditions

\begin{tabular}{c|c|c}
\hline Traits & Normal sowing & Late sowing \\
\hline Plant height & $61.1819^{* *}$ & $57.4181^{* *}$ \\
Tillers numbers per plant & $0.72056^{* *}$ & $1.29956^{*}$ \\
Days to heading & $25.5520^{*}$ & $12.6195^{* *}$ \\
Days to maturity & $20.1437^{* *}$ & $15.3067^{* *}$ \\
Grain filling duration & $16.2646^{* *}$ & $18.8524^{* *}$ \\
Harvest Index & $13.1339^{*}$ & $8.12861^{* *}$ \\
Grain filling Rate & $2.15689^{* *}$ & $8.01126^{*}$ \\
Grain weight per spike & $0.03896^{* *}$ & $0.12190^{*}$ \\
\hline
\end{tabular}

$*, * *$ Significant at $5 \%$ and $1 \%$, probability levels, respectively

Table 3. Growth and yield parameters of six generations means of Cross Miraj $2008 \times$ Punjab 2011 under normal and late sowing conditions with \% reduction under late sowing conditions

\begin{tabular}{c|c|c|c}
\hline Traits & Normal sowing & Late sowing & \% change \\
\hline Plant height & 101.81 & 76.747 & -24.4 \\
Tillers numbers per plant & 12.372 & 8.8756 & -28.3 \\
Days to heading & 96.200 & 84.393 & -12.3 \\
Days to maturity & 133.92 & 114.55 & -14.5 \\
Grain filling duration & 37.772 & 31.336 & -17.0 \\
Harvest Index & 42.377 & 30.878 & -27.1 \\
Grain Filling Rate & 94.535 & 81.857 & -13.4 \\
Grain weight per plant & 2.2550 & 1.4978 & -33.6 \\
\hline
\end{tabular}

\section{Phenological traits}

\section{Days to heading}

Heading time is phenological stage as it determines the pattern of yield potential and stability. When overall reduction percentage was exhibited from pooled means (Table 3) of both parents $\left(\mathrm{P}_{1}\right.$ and $\left.\mathrm{P}_{2}\right)$ and their generations $\left(\mathrm{F}_{1}, \mathrm{~F}_{2}, \mathrm{BC}_{1}\right.$ and $\left.\mathrm{BC}_{2}\right)$ the results depicted that growth span reduction percentage maximum in $\mathrm{BC}_{2}(15.81 \%)$ and minimum in $\mathrm{F}_{2}(10.28 \%)$, and when individual performance of parents and generation was investigated for mean values the response was different in both normal and late sowing conditions (Figure 1). In late sowing condition $\mathrm{F}_{2}$ depicted maximum mean value for days to heading (117.35) which revealed more variation in the segregating generation. Those observation were in line with the finding of Kilic and Yagbasanlar (2010). The study of controlling days to flowering is really pivotal as per genetic needs because genetic potentials would show negative indicators with the onset of erratic weather conditions. The genotypes with more days to heading in delayed planting 
conditions produce more grain yield because these genotypes assimilate nutrient from stem to kernels very precisely and grains enjoyed large size ultimately increased grain weight.

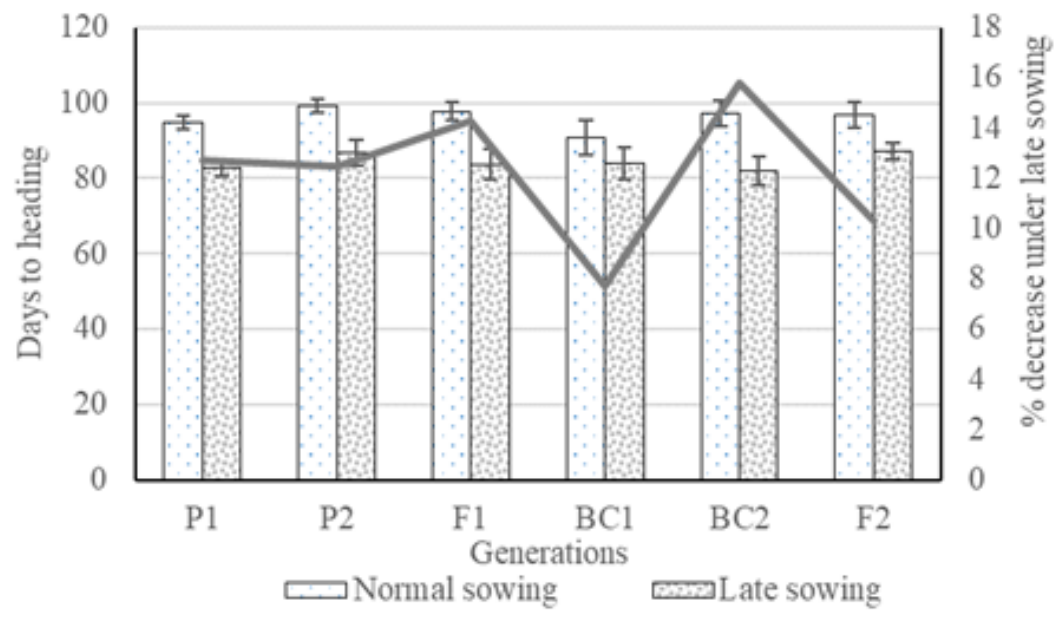

Figure 1. Days to heading of six generations of cross Miraj $2008 \times$ Punjab 2011 under normal and late sowing conditions along with \% increase or decrease. Error bar represents standard errors and overlapping bars are statistically at par with each other

\section{Days to maturity}

The stress environment forced early maturity and abridged the life cycle of the genotypes and their generation. $\mathrm{P}_{1}$ exhibited uppermost reduction percentage $(16.5 \%)$ for maturity days and lowermost $(11.52 \%)$ was revealed by $\mathrm{F}_{2}$ (Table 3 ). It means $\mathrm{P}_{1}$ was more sensitive to environmental stress. While in late sowing date $F_{2}$ depicted highest days to maturity (117.3) and lowest magnitude (112.2) were documented for $\mathrm{BC}_{1}$ (Figure 2). Those statement were also analogous with the finding of Kilic and Yagbasanlar (2010).

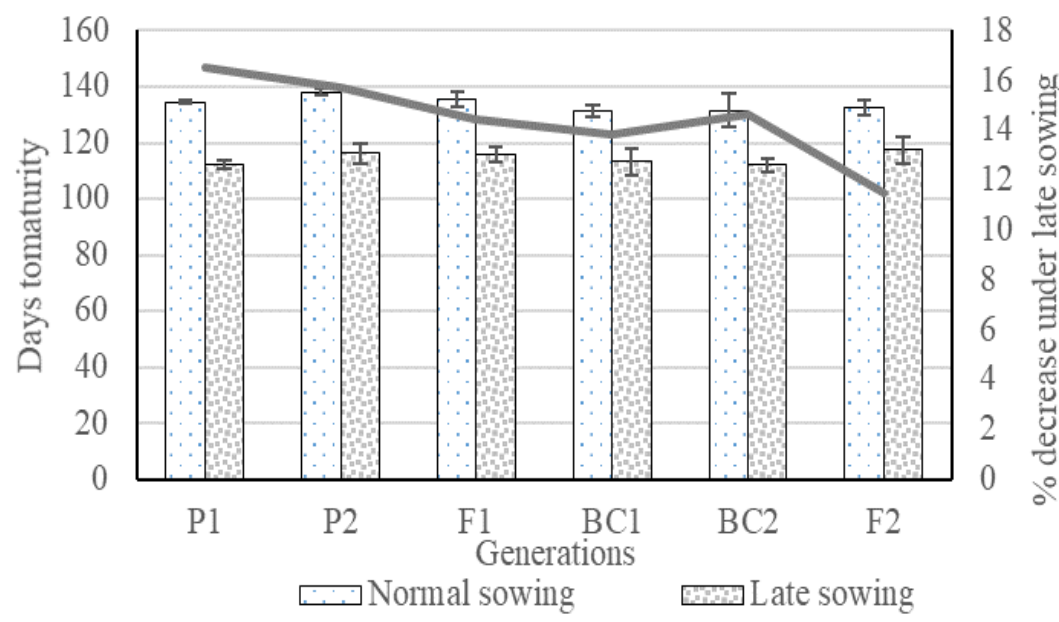

Figure 2. Days to maturity of six generations of cross Miraj $2008 \times$ Punjab 2011 under normal and late sowing conditions along with \% increase or decrease. Error bar represents standard errors and overlapping bars are statistically at par with each other 


\section{Grain filling duration}

When genotypes were sown in normal dates more grain filling days were produced comparative to late sowing (Table 3). For grain filling duration in pooled mean values of both parents and generations back cross 1 attained highest reduction (27.9\%) percentage while lowest value $(13.59 \%)$ was noted in $\mathrm{F}_{2}$ depicted in Figure 3. The losses percentage was out of parents range. In late planting conditions $\mathrm{P}_{2}$ (33.86) illustrated maximum grain filling days and $P_{1}$ (28.60) showed lowest value when separate performance of parents and generations was observed. Delayed sowing shortens the duration of each development phase which ultimately reduces grain filling period resulting in lower grain weight (Kaur, 2017). It additionally shows that the optimum planted genotype relished a prolonged development stage and favorable preheading environments, which have had a persist impact on grain weight via stem reserves mobilization (Baloch et al., 2012).

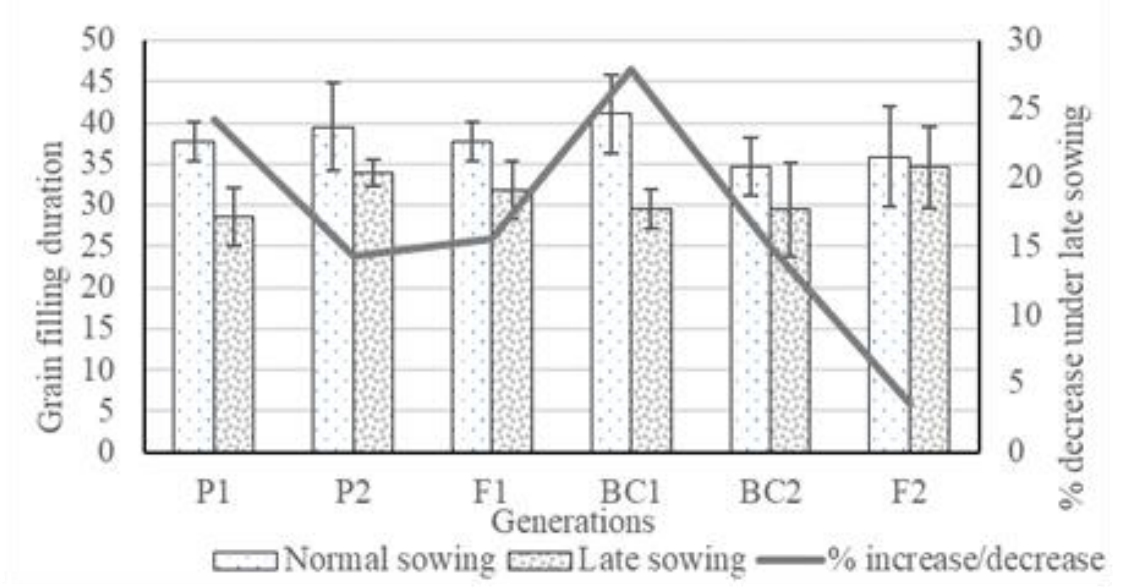

Figure 3. Grain filling duration of six generations of cross Miraj $2008 \times$ Punjab 2011 under normal and late sowing conditions along with \% increase or decrease. Error bar represents standard errors and overlapping bars are statistically at par with each other

\section{Grain filling rate}

It is also an important penolohgiacal trait. In pooled mean values for both parents and their generations $\mathrm{P}_{1}$ showed maximum reduction percentage magnitude $(14.96 \%)$ and minimum value showed by $\mathrm{F}_{2}$ that was $(11.52 \%)$. For observing individual performance in all generation and parents under both normal and late sowing trial the uppermost mean magnitude revealed by $\mathrm{F}_{2}$, while the lowermost value was perceived by $\mathrm{BC}_{1}$ (93.41) in normal and $\mathrm{P}_{1}$ (80.05) scored minimum in late planting experiment (Figure 4). Similar results were presented by Tahir et al. (2009), Laghari et al. (2012) and Golparvar (2012). Grain filling rate is critical growth phase where hostile environmental circumstances leads to harmful effect on grain yield and quality. Delay planting face high temperature at the time of maturity and reduced grain filling duration. It has been noted in the recent studies high temperature stress increase rate of stem reservoir mobilization towards grain filling but not reimburse for short grain filling days (Farooq et al., 2011). Due to this reason grain could not reach maximum size ultimately decline in grain yield occured. 


\section{Harvest index}

It may be explained as translocation of nutrients from vegetative part to reproductive part. In pooled mean value of both parents and generations, highest reduction percentage was noted in $\mathrm{F}_{2}$ segregating generation $(32.89 \%)$ while the lowest percentage was revealed by $F_{1}(23.62 \%)$ of cross Miraj $2008 \times$ Punjab 2011. while in detecting individual performance of parents and generations under normal planting trial $\mathrm{F}_{2}$ represented $(44.10 \%)$ highest mean value and $\mathrm{BC}_{2}$ showed $(38.59 \%)$ the lowest value, whereas in late planting trial $\mathrm{P}_{2}$ obtained (32.23\%) highest mean value (Figure 5 ). Harvest index deliver fruitful information regarding selection of genotypes in late sowing conditions. It has been noted in literature the genotypes with more harvest index attained more biomass and performed well in delay sowing conditions (Akram, 2011; Mushtaq et al., 2011).

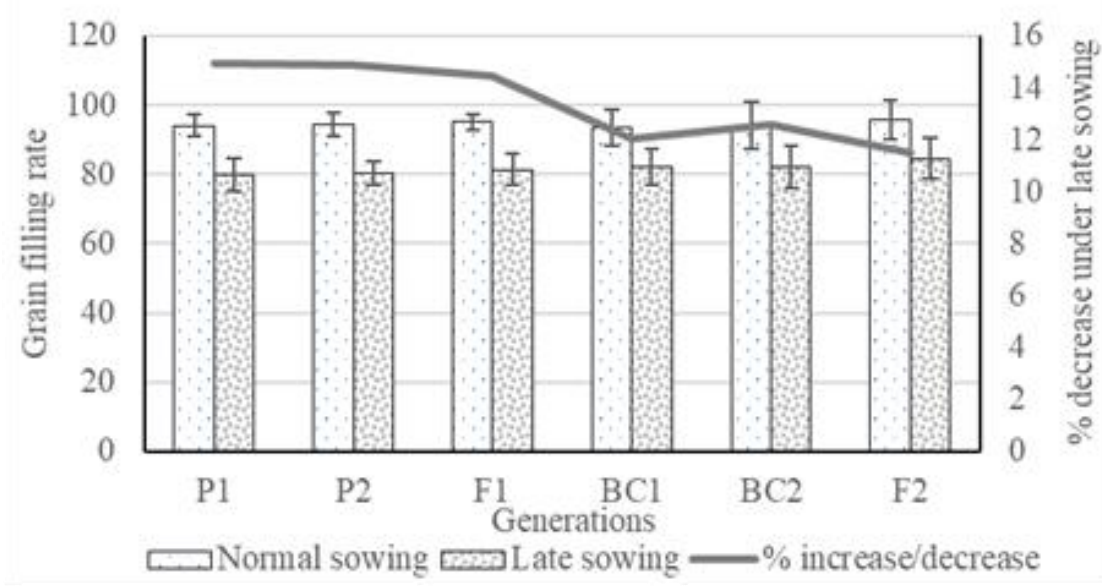

Figure 4. Grain filling rate of six generations of cross Miraj $2008 \times$ Punjab 2011 under normal and late sowing conditions along with \% increase or decrease. Error bar represents standard errors and overlapping bars are statistically at par with each other

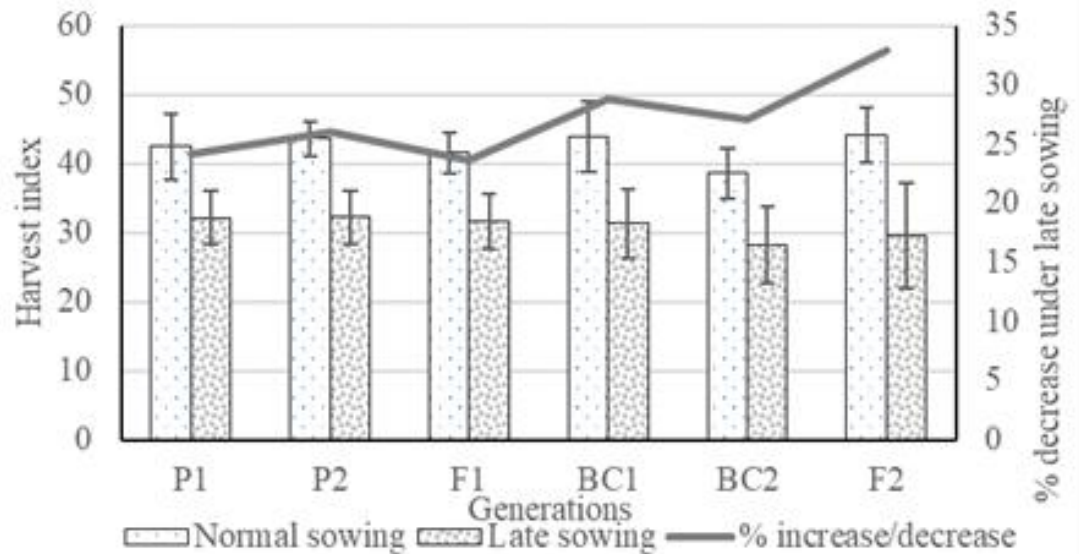

Figure 5. Harvest index of six generations of cross Miraj $2008 \times$ Punjab 2011 under normal and late sowing conditions along with \% increase or decrease. Error bar represents standard errors and overlapping bars are statistically at par with each other 


\section{Morphological and yield related traits}

The yield associated traits like Plant height (Figure 6), tillers number per plant (Figure 7) and grain weight per spike (Figure 8) were advisedly affected under late sowing conditions. Grain weight per spike revealed maximum decline, as all other yield related traits add up to decrease grain yield in delay planting condition. To select genotypes with optimum plant height with vigorous vegetative growth is painstaking criteria. Tillering in wheat crop help to compensate the yield even though plant population is not met adequately. Number of tillers per plant is reportedly decreased with the onset of late planting due to less growing degree days. Grain weight per spike is more sensitive trait under late sowing conditions.

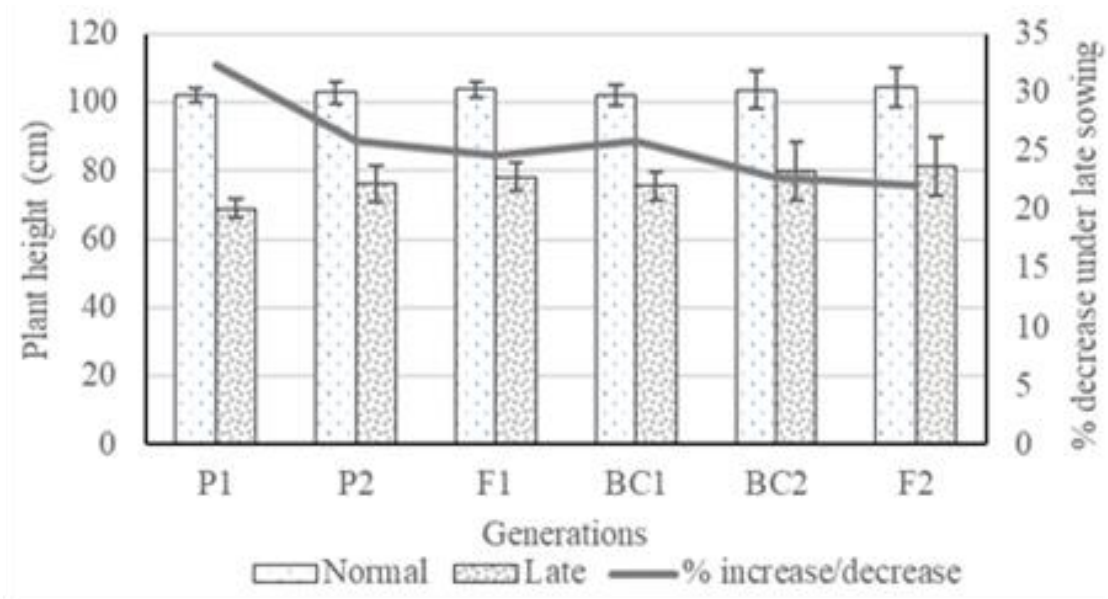

Figure 6. Plant height of six generations of cross Miraj $2008 \times$ Punjab 2011 under normal and late sowing conditions along with \% increase or decrease. Error bar represents standard errors and overlapping bars are statistically at par with each other

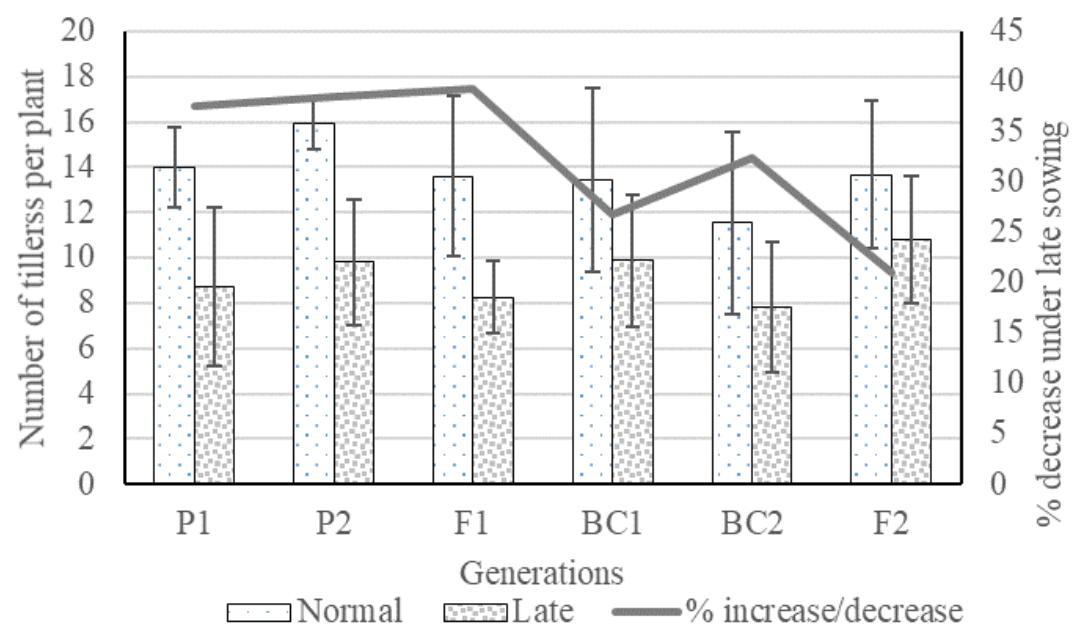

Figure 7. Tillers number per plant of six generations of cross Miraj $2008 \times$ Punjab 2011 under normal and late sowing conditions along with \% increase or decrease. Error bar represents standard errors and overlapping bars are statistically at par with each other 


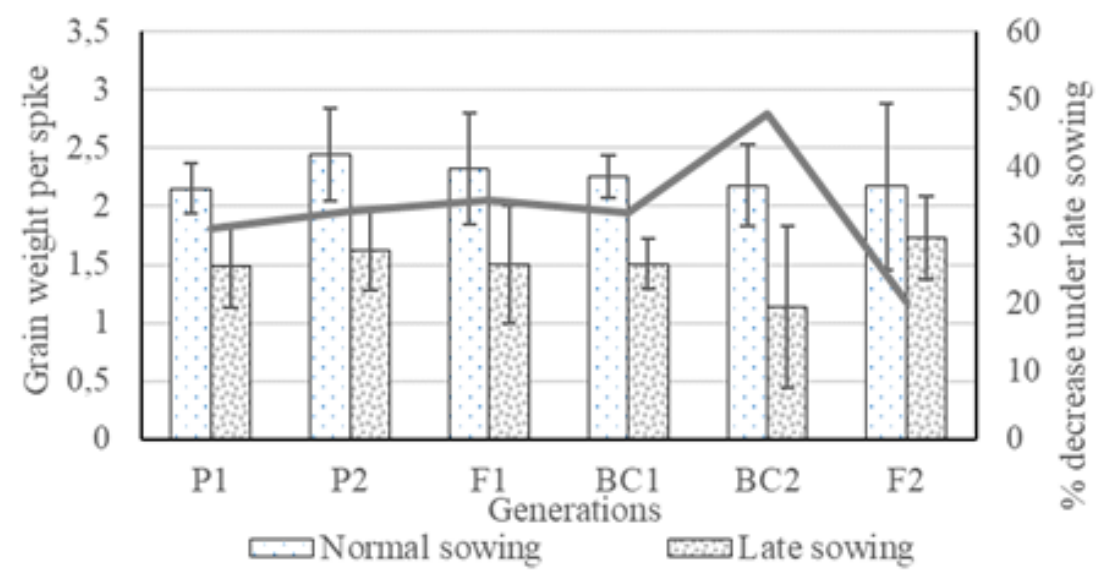

Figure 8. Grain weight per spike of six generations of cross Miraj $2008 \times$ Punjab 2011 under normal and late sowing conditions along with \% increase or decrease. Error bar represents standard errors and overlapping bars are statistically at par with each other

\section{Gene action}

Generation mean analysis was employed to assess the mean [m], additive [d], dominance [h], additive $\times$ additive [i], additive $\times$ dominance [ $\mathrm{j}$ ] and dominance $\times$ dominance [1] gene actions and magnitudes. The best efficacy of model was selected using two things i.e. lowest standard error and non-significant value of chi square $\chi^{2}$ test for all traits under observation. For the detection of inheritance array in normal conditions for plant height five parameter model was best and vastly presence of additive [d] genetic effect than dominance [h], while the adequacy of three parameter model in late sowing conditions observed best fitted. Additive $\times$ additive [i] gene effects were significant. This suggests that selection should be carried out in later generations and the interaction should be fixed by selection under selfing conditions. These results are agreed with the observation of Farshadfar et al. (2001). Ojaghi and Akhundova (2010) noted additive, while conflicting results were depicted by Saleem et al. (2016). For tillers number per plant significant additive genetic effects with epistatic effects were also recorded. Additive $\times$ additive [i] interaction is more valuable for genetic improvement of characters through selection. In normal planting condition five [mdhij] and four [mdhi] parameter models in late planting conditions were observed best tailored to explain the genetic variation existed in breeding material for number of tiller per plant. Such type of findings were documented via Badran and Moustafa (2014) and conflicting conclusion were publicized by Ullah et al. (2010) and Rashid et al. (2012). Generation mean analysis revealed that days to heading was governed by polygenes i.e., complex genetic inheritance. The negative magnitude of [i] additive $\times$ additive epistatic effect showed in late sowing conditions gene expression not fully expressed in stressed condition and nature of epistasis was duplicate as main additive effect [d] were also reported. Five parameters [mdhij] in late and four [mdhi] parameter models obtained best fit to examine the variation in inheritance pattern (Table 4). Zara-Kohan and Heidari (2012) witnessed similar results. They revealed both fixable and non-fixable gene action. According to the nature of treatments in cross for days taken to maturity five parameter model [mdhij] was investigated fit for detection of gene action under both planting conditions. Hybrid breeding is fruitful for selection of trait because 
prominent dominant $[\mathrm{h}]$ effect was paving. In normal planting non fixable gene action somewhat more percentage than fixable gene action.

Additive type of gene action was prominent in grain filling period in normal planting conditions with [i] and [j] epistatic effects but under late planting conditions change in gene action was witnessed (Table 4). It viewed under the effect of environment and duplicate type of epistasis was found because of main dominance effect [h] and epistatic dominance $\times$ dominant [1] effect had opposite sign under late planting time. The similar situation was examined by Nazeer et al. (2004). Zara-Kohan and Heidari (2012) reported selection in stable generation would be fruitful due to governing of non-fixable type of gene action for this parameter. For the inheritance of grain filing rate under late planting conditions four parameter model [mdhl] was found best fit (Table 4).

Table 4. Estimates of the best fit model for generation means parameters ( \pm , standard error) by weighted least squares analysis in cross Miraj $2008 \times$ Punjab 2011 under normal and late sowing conditions

\begin{tabular}{|c|c|c|c|c|c|c|c|c|}
\hline \multirow[t]{2}{*}{ Traits } & \multirow[t]{2}{*}{ Cross } & \multicolumn{6}{|c|}{ Genetic Effects } & \multirow[t]{2}{*}{$\chi^{2}$ (df) } \\
\hline & & $\mathbf{m} \pm \mathbf{S . E}$ & {$[\mathbf{d}] \pm$ S.E } & {$[\mathbf{h}] \pm \mathbf{S . E}$} & {$[\mathbf{i}] \pm$ S.E } & {$[\mathbf{j}] \pm \mathbf{S . E}$} & {$[\mathbf{I}] \pm$ S.E } & \\
\hline \multirow{2}{*}{$\begin{array}{l}\text { Plant } \\
\text { height }\end{array}$} & $\mathrm{N}$ & $124.21 \pm 3.06$ & $4.48 \pm 0.231$ & $49.54 \pm 8.07$ & $25.61 \pm 3.05$ & - & $31.84 \pm 5.13$ & $0.2864(1)$ \\
\hline & $\mathrm{L}$ & $84.40 \pm 1.05$ & $3.61 \pm 0.23$ & & $11.79 \pm 1.08$ & - & & $0.8651(3)$ \\
\hline \multirow{2}{*}{$\begin{array}{c}\text { Tiller } \\
\text { number } \\
\text { per } \\
\text { plant }\end{array}$} & $\mathrm{N}$ & $11.53 \pm 0.53$ & $0.19 \pm 0.20$ & $1.05 \pm 0.79$ & $1.22 \pm 0.57$ & $7.10 \pm 1.45$ & - & $1.7860(1)$ \\
\hline & $\mathrm{L}$ & $7.18 \pm 0.42$ & $0.41 \pm 0.14$ & $1.04 \pm 0.40$ & $1.97 \pm 0.45$ & - & & $4.455(2)$ \\
\hline \multirow{2}{*}{$\begin{array}{l}\text { Days to } \\
\text { heading }\end{array}$} & $\mathrm{N}$ & $97.03 \pm 0.16$ & $2.47 \pm 0.15$ & $5.45 \pm 0.88$ & $6.21 \pm 0.90$ & - & - & $1.7548(2)$ \\
\hline & $\mathrm{L}$ & $88.96 \pm 0.65$ & $1.95 \pm 0.22$ & $-5.42 \pm 0.80$ & $4.35 \pm 0.70$ & $-7.55 \pm 1.58$ & - & $1.1269(1)$ \\
\hline \multirow{2}{*}{$\begin{array}{l}\text { Days to } \\
\text { maturity }\end{array}$} & $\mathrm{N}$ & $136.87 \pm 0.43$ & $1.73 \pm 0.12$ & $1.99 \pm 0.62$ & $0.80 \pm 0.45$ & $1.42 \pm 0.32$ & - & $1.9142(1)$ \\
\hline & $\mathrm{L}$ & $133.24 \pm 1.90$ & $1.77 \pm 0.20$ & $46.30 \pm 4.99$ & $-18.92 \pm 1.89$ & $28.97 \pm 3.20$ & - & $1.5337(1)$ \\
\hline \multirow{2}{*}{$\begin{array}{c}\text { Grain } \\
\text { filling } \\
\text { duration }\end{array}$} & $\mathrm{N}$ & $34.27 \pm 0.52$ & $0.88 \pm 0.22$ & $-3.60 \pm 0.72$ & $4.44 \pm 0.57$ & $-14.58 \pm 1.30$ & - & $1.9844(1)$ \\
\hline & $\mathrm{L}$ & $31.23 \pm 0.24$ & $2.63 \pm 0.24$ & $6.19 \pm 1.02$ & - & - & $-5.47 \pm 1.34$ & $1.2870(2)$ \\
\hline \multirow{2}{*}{$\begin{array}{c}\text { Harvest } \\
\text { index }\end{array}$} & $\mathrm{N}$ & $38.79 \pm 0.51$ & $0.567 \pm 0.21$ & $2.76 \pm 0.68$ & $4.236 \pm 0.56$ & $11.81 \pm 1.17$ & - & $0.0158(1)$ \\
\hline & $\mathrm{L}$ & $26.84 \pm 0.74$ & $1.01 \pm 0.27$ & $4.43 \pm 1.23$ & $-5.24 \pm 0.81$ & & $6.58 \pm 1.37$ & $2.2183(1)$ \\
\hline \multirow{2}{*}{$\begin{array}{l}\text { Grain } \\
\text { filling } \\
\text { rate }\end{array}$} & $\mathrm{N}$ & $94.48 \pm 0.27$ & $0.44 \pm 0.17$ & $3.79 \pm 1.48$ & $4.78 \pm 2.19$ & - & $2.99 \pm 1.22$ & $0.1496(1)$ \\
\hline & $\mathrm{L}$ & $80.70 \pm 1.28$ & $5.19 \pm 1.12$ & $8.50 \pm 5.04$ & - & - & $7.72 \pm 2.22$ & $1.1150(2)$ \\
\hline \multirow{2}{*}{$\begin{array}{c}\text { Grain } \\
\text { weight } \\
\text { per } \\
\text { spike }\end{array}$} & $\mathrm{N}$ & $2.01 \pm 0.06$ & $0.14 \pm 0.02$ & - & - & $-0.44 \pm 0.20$ & & $4.5642(3)$ \\
\hline & $\mathrm{L}$ & $1.55 \pm 0.01$ & $0.06 \pm 0.01$ & $0.80 \pm 0.10$ & - & $-0.88 \pm 0.12$ & $0.74 \pm 0.10$ & $1.2521(1)$ \\
\hline
\end{tabular}

$\mathrm{N}=$ normal sowing, $\mathrm{L}=$ late sowing conditions

Due to presence of non-allelic interaction this attribute was governed by multiple genes. Hybrid breeding is done for the improvement of grain filling rate due to presence of dominance component $[h]$. To obtain maximum grain filing rate selection could be done in succeeded generations. These results are lined with Nazeer et al. (2010) and clashing conclusions obtained by Ullah et al. (2010). For harvest index five parameters models i.e. [mdhij] and [mdhil] were found best fit under both normal and late planting environments. In late sowing condition [i] epistatic gene action showed negative sign which exhibited that gene interacting with one another (Table 4). Due to presence of main dominance effect $[\mathrm{h}]$ and dominant $\times$ dominant [1] selection can also performed in later generation and also hybrid breeding for harvest index would be fruitful. Farshadfar 
et al. (2001) displayed same type of conclusion while. Grain weight per spike five parameter model [mdhjl] was adequate to elucidate the gene inheritance in late planting environment (Table 4). In order to attain higher grain weight per spike selection in succeeded generation could be helpful. Parallel results are confirmation with Amin (2006) and El-Rahman (2013).

\section{Heritability studies}

Estimation of heritability is another important estimate in order to understand the potential of characters to be improved through selection and also tells about the possibility of accumulation of favorable gene in the successive generation after selection. It also indicates the amount of genetic variability relative to environmental affects and is considered a good index of transmission of characters from parents to their offspring. Under normal sowing conditions range of narrow sense heritability was from 0.35 to 0.90 (Table 5). Most of the examined traits revealed moderate to high heritability except grain filling rate and grain weight per spike. The range $(0.23$ to 0.71$)$ was observed under late sowing conditions (Table 5). Low to medium narrow-sense heritability can be attributed to the reduction of genetic variability in the late sowing environment. The higher heritability value will make the selection process effective, which will result in higher response. Selection of traits with high heritability in early generation is more fruitful. Abinasa et al. (2011) and Saleem et al. (2016) found high heritability for plant height, days to heading and days to maturity. While moderate type of heritability was observed by Nazeer et al. (2010). Zara-Kohan and Heidari (2012) and Khan and Naqvi (2011) have also noted high heritability for grain filling period. The reduction in heritability value under late sowing conditions indicated that gene responsible for the heritability of trait do not expressed themselves strongly in late sowing. Usually late sowing produce early senescence hence decrease in grain filling period causing reduction in yield. Therefore the genotypes which have longer grain filling period under stress conditions would be better yielder.

Table 5. Estimation of narrow sense heritability of different traits under studied

\begin{tabular}{c|c|c}
\hline Traits & Normal sowing & Late sowing \\
\hline Plant height & 0.90 & 0.67 \\
Tiller number per plant & 0.76 & 0.23 \\
Days to heading & 0.89 & 0.71 \\
Days to maturity & 0.78 & 0.55 \\
Grain filling duration & 0.64 & 0.26 \\
Harvest index & 0.62 & 0.65 \\
Grain filling rate & 0.35 & 0.33 \\
Grain weight per spike & 0.47 & 0.41 \\
\hline
\end{tabular}

\section{Conclusion}

Optimum sowing date for any cultivar is very crucial to accumulate ample dry matter and grain weight per spike yet to elude potential yield losses form high temperature stress during critical time mainly flowering initiation to grain filling stage. Genetic analysis showed that all traits under study were under the control of complex inheritance due to presence of epistasis. So, selection for these traits would be done in 
later generations when combinations fixed. The phenological traits grain filling rate, grain filling duration and harvest index considered pivotal for the development of genotypes in late sowing conditions. So, for efficient breeding utilization of these phenological traits like grain filling rate, grain filling duration and harvest index are necessary to improve crop yield for late sowing wheat areas.

\section{REFERENCES}

[1] Abinasa, M., Ayana, A., Bultosa, G. (2011): Genetic variability, heritibiity and trait association in durum wheat (Triticum turgidum. L. var. durum) genotypes. - African Journal of Agricultural Research 6(17): 3972-3979.

[2] Akram, M. (2011): Growth and yield components of wheat under water stress of different growth stages. - Bangladaish Journal of Agricultural Research 36(3): 455-468.

[3] Alghabari, F., Lukac, M., Jones, H. E., Gooding, M. J. (2014): Effect of Rht alleles on the tolerance of wheat grain set to high temperature and drought stress during booting and anthesis. - Journal of Agronomy and Crop Science 200: 36-45.

[4] Amin, I. A. (2006): Genetic behaviour of some agronomic traits in two durum wheat crosses under heat stress. - Alex Journal of Agriculture Research 58: 53-66.

[5] Badran, A. E., Moustafa, E. S. A. (2014): Genetic parameters of some wheat (Triticum aestivum L.) genotypes using factorial mating design. - Journal of Agricultural Sciences 7: 101-105.

[6] Baloch, M. S., Nadim, M. A., Zubair, M., Awan, I. U., Khan, E. A., Ali, S. (2012): Evaluation of wheat under normal and late sowing conditions. - Pakistan Journal of Botany 44(5): 1727-1732.

[7] Barnabas, B., Jager, K., Feher, A. (2008): The effect of drought and heat stress on reproductive processes in cereals. - Plant Cell Environment 3: 11-38.

[8] El-Rahman, M. E. A. (2013): Estimation of some genetic parameters through generation mean analysis in three bread wheat crosses. - Alexandria Journal of Agricultural Research 58(3): 183-195.

[9] Farooq, M., Bramley, H., Palta, J. A., Sidique, K. H. M. (2011): Heat stress in wheat during reproductive and grain fi lling phases. - Critical Review of Plant Sciences 30: 491507.

[10] Farshadfar, E., Ghanadha, Sutka, J., Zahravi, M. (2001): Generation mean analysis of drought tolerance in wheat (Triticum aestivum L.). - Acta Agron. Hung. 49(1): 59-66.

[11] Golparvar, A. R. (2012): Heritability and mode of gene action determination for grain filling rate and relative water content in hexaploid wheat. - Genetika 44: 25-32.

[12] Gupta, N. K., Agarwal, S., Agarwal, V. P., Nathawa, N. S., Gupta, S., Singh, G. (2013): Effect of short-term heat stress on growth, physiology and antioxidative defence system in wheat seedlings. - Acta Physiology of Plant 35: 1837-1842.

[13] IFPRI. (2009): International Food Policy Research Institute. - www.ifpri.org.

[14] Jena, T., Singh, R. K., Singh, M. K. (2017): Mitigation measures for wheat production under heat stress condition. - International Journal Agricultural Science and Research 7(1): 359-376.

[15] Kaur, C. (2017): Performance of Wheat Varieties under Late and Very Late Sowing Conditions. - International Journal of Current Microbiology and Applied Sciences 6(9): 3488-3492.

[16] Khan, N., Naqvi, F. N. (2011): Heritability in morphological traits in bread wheat advanced lines under irrigated and non-irrigated conditions. - Asian Journal of Agricultural Sciences 3(3): 215-222. 
[17] Kilic, H., Yagbasanllar, T. (2010): The effect of drought stress on grain yield, yield components and some quality traits of durum wheat cultivars. - Notulae Botanicae Horti AgrobotaniciCluj-Napoca 38(1): 164-170.

[18] Laghari, K. A., Sial, M. A., Arain, M. A., Khanzada, S. D., Channa, S. A. (2012): Evaluation of stable wheat mutant lines for yield and yield associated traits. - Pakistan Journal of Agriculture Agricultural Engineering and Veterinary 28(2): 124-130.

[19] Mather, K., Jinks, J. L. (1982): Biometrical Genetics ( $3^{\text {rd }}$ ed.). - Champman and Hall Ltd.- London- UK.

[20] Mirshekarnezhad, B., Paknejad, F., Amiri, E., Ardakani, M. R., Ilkaee, M. N. (2018): Functional strategies for certain growth stages of corn in response to environmental factors: irrigation and planting date management. - Applied Ecology and Environmental Research 16(5): 6169-6180.

[21] Mushtaq, T., Hussain, S., Bukhsh, M. A. H. A., Iqbal, J., Khaliq, T. (2011): Evolution of two wheat genotypes performance under stress condition at different growth stages. Crop and Environment 2(2): 20-27.

[22] Nazeer, W. A., Hassan, M. S. U., Akram, Z. (2004): Genetic artichitecture of some agronomic traits in diallel cross of bread wheat. - Pakistan Journal of Biological Sciences 7(8): 1340-1342.

[23] Nazeer, W., Ali, Z., Ali, A., Hussain, T. (2010): Genetic behavior of some polygenetic yield contributing traits in wheat (Triticum aestivum L). - Journal of Agricultural Research 48(3): 267-277.

[24] Ojaghi, J., Akhundova, E. (2010): Genetic effects of grain yield and its related traits in double haploid lines of wheat. - International Journal of Agriculture and Biology 12(1): 86-90.

[25] Prasad, P. V. V., Pisipati, S. R., Momcilovic, I., Ristic, Z. (2011): Independent and combined effects of high temperature and drought stress during grain filling on plant yield and chloroplast ef-tu expression in spring wheat. - Journal of Agronomy and Crop Science 197(6): 430-441.

[26] Rashid, M. A. R., Khan, A. S., Iftikhar, R. (2012): Genetic studies for yield and yield related parameters in bread wheat. - American-Eurasian Journal of Agricultural and Environmental Sciences 12: 1579-1583.

[27] Saleem, S., Kashif, M., Hussain, M., Khan, A. S., Saleem, M. F. (2016): Genetic behavior of morpho-physiological traits and their role for breeding drought tolerant wheat. Pakistan Journal of Botany 48(3): 925-933.

[28] Saxena, N. P., Toole, J. C. O. (2002): Field screening for drought tolerance in crop plants with emphasis on rice. - Proceedings of an international workshop on field screening for drought tolerance in rice, 11-14 Dec 2000, ICRISAT, Patancheru, India - Patancheru 502 324, Andhra Pradesh, India, and the Rockefeller Foundation, New York, New York 10018-2702, USA. 208 pp.

[29] Sohail, M., Hussain, I., Riaz-ud-Din, Tanveer, S. K., Qamar, M., Abbas, S. H. (2014): Evaluation of advance wheat lines for agronomic traits in rain fed environment. Pakistan Journal of Agricultural Sciences 27(2): 79-88.

[30] Steel, R. G. D., Torrie, J. H., Dickey, D. A. (1997): Principles and Procedures of Statistics: A biometrical approach ( $3^{\text {rd }}$ ed.). - McGraw Hill Book Co., New York, USA.

[31] Tahir, M., Ali, A., Nadeem, M. A., Hussain, A., Khalid, F. (2009): Effect of different sowing dates on growth and yield of wheat (Triticum aestivum L.) genotypes in District Jhang, Pakistan. - Pakistan Journal of Life and Social Sciences 7(1): 66-69.

[32] Ullah, S., Khan, A. S., Raza, A., Sadique, S. (2010): Gene action analysis of yield and yield related traits in spring wheat (Triticum aestivum L). - International Journal of Agriculture and Biology 12: 125-128.

[33] Zara-Kohan, M., Heidari, B. (2012): Estimation of genetic parameters for maturity and grain yield in diallel crosses of five wheat cultivars using two different models. - Journal of Agricultural Science 4(8): 74-85. 